\title{
PENGARUH REKRUTMEN, PENEMPATAN KERJA DAN KOMPENSASI TERHADAP KINERJA KARYAWAN PT INDOTURBINE JAKARTA PUSAT
}

\author{
Muhammad Alwi ${ }^{1}$ \\ Edi Sugiono ${ }^{2}$ \\ ${ }^{1,2}$ Fakultas Ekonomi dan Bisnis Universitas Nasional \\ Email: alwimuhammad482@gmail.com ${ }^{1}$, edisugiono33@ yahoo.com ${ }^{2}$
}

\begin{abstract}
ABSTRAK
Penelitian ini bertujuan untuk menganalisis pengaruh rekrutmen, penempatan kerja, dan kompensasi terhadap kinerja karyawan PT Indoturbine Jakarta Pusat. Penelitian ini mengunakan data primer yang diperoleh dari penyebaran kuesioner kepada 116 orang karyawan dan dianalisis mengunakan metode analisis regresi linear berganda. Hasil penelitian menunjukkan bahwa rekrutmen, penempatan kerja, dan kompensasi secara parsial berpengaruh positif dan signifikan terhadap kinerja karyawan PT Indoturbine Jakarta Pusat.
\end{abstract}

Kata kunci: Rekrutmen, penempatan kerja, kompensasi, kinerja karyawan

\section{ABSTRACT}

This study aims to analyze the effect of recruitment, job placement, and compensation on employee performance of PT Indoturbine Central Jakarta. This study used primary data obtained from the distribution of questionnaires to 116 employees and analyzed using multiple linear regression analysis methof. The results showed that recruitment, job placement, and compensation partially have positive and significant effect on the employee performance of PT Indotyrbine Central Jakarta.

Keywords: Recruitment, job placement, compensation, employee performance

\section{PENDAHULUAN}

Keberadaan sumber daya manusia memegang peranan yang sangat penting dalam suatu perusahaan karena perusahaan tidak akan mampu beroperasional tanpa adanya keterlibatan dari sumber daya manusia. Dalam hal ini, sumber daya manusia bahkan memegang unsur pengendalian dari suatu perusahaan, sehingga keberhasilan dari perusahaan yang bersangkutan jelas sangat bergantung pada sumber daya manusia tersebut. Oleh sebab itu, perusahaan membutuhkan karyawan berkualitas yang mampu berkinerja dan berprestasi kerja yang tinggi dalam rangka membantunya untuk mencapai tujuan karena kinerja pegawai dalam suatu perusahaan akan secara langsung berdampak terhadap kinerja dari perusahaan itu sendiri secara keseluruhan.

Bangun (2012) mendefinisikan kinerja sebagai variabel dependen yang dipengaruhi oleh banyak faktor yang mengandung makna dalam penyampaian tujuan organisasi. Hal 
tersebut menunjukkan bahwa kesalahan dalam pengelolaan variabel bebas yang berkaitan dengan kinerja tersebut pada akhirnya akan menimbulkan suatu dampak tertentu terhadap kinerja, baik secara negatif maupun positif. Dalam rangka meningkatkan kinerja karyawannya untuk mencapai tujuan, maka perusahaan perlu untuk mengelola variabelvariabel bebas yang berpengaruh signifikan terhadap kinerja ke arah yang lebih baik.

Sebagai sebuah perusahaan yang bergerak di bidang penjualan barang modal yang tergolong ke dalam alat berat untuk pertambangan migas dan industri tertentu, volume fluktuasi penjualan PT Indoturbine seringkali mengalami fluktuasi dari satu periode ke periode lainnya. Sementara itu, beban biaya yang harus ditanggung oleh perusahaan justru berkecenderungan untuk terus naik seiring dengan kenaikan harga secara umum. Padahal, PT Indoturbine pada dasarnya memiliki tujuan utama yang sama dengan perusahaan lainnya, yakni untuk memperoleh laba dari usaha yang dijalaninya. Akan tetapi, fluktuasi penjualan yang dialami PT Indoturbine selama periode 2015-2017, misalnya, dapat menjadi indikasi awal atas adanya pelambatan kinerja yang dapat menghambat pencapaian tujuan perusahaan. Oleh sebab itu, diperlukan pengelolaan yang tepat terhadap beberapa variabel yang relevan untuk mempengaruhi kinerja karyawan dan perusahaan secara umumnya ke arah yang lebih baik.

Salah satu kunci utama dalam pengembangan sumber daya manusia yang berkualitas tinggi adalah rekrutmen. Hal tersebut didukung oleh hasil penelitian yang dilakukan oleh Aziz, dkk. (2017) dan Kartodikromo, dkk. (2017) yang menunjukkan bahwa rekrutmen berpengaruh positif dan signifikan terhadap kinerja karyawan. Akan tetapi, hasil penelitian yang dilakukan oleh Atikawati dan Udjang (2016) justru menunjukkan bahwa rekrutmen tidak berpengaruh signifikan terhadap kinerja karyawan.

Agar karyawannya dapat didayagunakan secara optimal, perusahaan juga dinilai perlu untuk memiliki sistem penempatan kerja yang tepat untuk setiap divisi yang ada dalam perusahaan itu sendiri. Hal ini sejalan dengan hasil penelitian yang dilakukan oleh Aldilaningsari, dkk. (2014) yang menunjukkan bahwa penempatan kerja yang memperhatikan kesesuaian pengetahuan, kemampuan, dan keterampilan terbukti berpengaruh positif dan signifikan terhadap kinerja karyawan. Muaja, dkk. (2017) juga berhasil membuktikan adanya pengaruh positif dan signifikan dari penempatan kerja terhadap kinerja karyawan. 
Faktor lain yang dinilai dapat mempengaruhi kinerja karyawan adalah kompensasi. Hal ini telah dibuktikan oleh Maharani dan Efendi (2017) dalam hasil penelitiannya yang menunjukkan bahwa kompensasi berpengaruh positif dan signifikan terhadap kinerja karyawan. Keduanya menjelaskan bahwa pemberian kompensasi yang efektif dapat mendorong karyawan untuk menjalankan tugas dan pekerjaannya sebaik mungkin, sehingga pada akhirnya akan mampu untuk meningkatkan kinerja karyawan.

Berdasarkan uraian latar belakang di atas, maka dikembangkanlah penelitian untuk menganalisis pengaruh rekruitmen, penempatan kerja, dan kompensasi terhadap kinerja karyawan PT Infoturbine Jakarta Pusat.

\section{TINJAUAN PUSTAKA}

\section{Rekrutmen}

Penarikan (rekrutmen) karyawan adalah suatu proses yang dilakukan oleh perusahaan untuk memperoleh tambahan karyawan melalui tahapan yang meliputi pengidentifikasian dan pengevaluasian terhadap sumber-sumber penarikan pegawai, penentuan kebutuhan pegawai, pelaksanaan proses seleksi, serta penempatan dan pengorientasian pegawai (Mangkunegara, 2011). Menurut Sutisna (2011:37), rekrutmen merupakan suatu proses pencarian, penemuan, dan penarikan para pelamar untuk dipekerjakan dalam suatu organisasi. Lebih jauh lagi, Rivai (2011) menjelaskan rekrutmen sebagai serangkaian kegiatan yang dimulai saat suatu perusahaan membutuhkan tenaga kerja dan membuka lowongan pekerjaan, hingga sampai perusahaan tersebut mendapatkan calon yang diinginkan atau yang memenuhi kualifikasi sesuai jabatan atau lowongan yang tersedia.

Menurut Hasibuan (2012), penarikan calon karyawan dapat berasal dari dua sumber sebagai berikut.

\section{Sumber Internal}

Pada sumber ini, karyawan yang akan dipekerjakan untuk mengisi suatu lowongan kerja diambil dari dalam perusahaan itu sendiri dengan jalan melakukan mutasi atau pemindahan terhadap karyawan yang memenuhi spesifikasi jabatan yang bersangkutan. Sumber-sumber internal itu sendiri antara lain mencakup: (a) penawaran terbuka untuk suatu jabatan (job posting program), yakni sistem mencari pekerjaan yang berkemampuan tinggi untuk mengisi jabatan yang lowong dengan jalan memberi 
kesempatan kepada seluruh karyawan yang berminat; dan (b) perbantuan pekerjaan (departing employees), yakni rekrutmen yang dapat dilakukan melalui perbantuan pekerja untuk suatu jabatan dari unit kerja lain.

2. Sumber Eksternal

Pada sumber eksternal, karyawan yang akan dipekerjakan untuk mengisi jabatan yang kosong adalah orang-orang yang berasal dari sumber-sumber di luar perusahaan, mulai dari kantor penempatan tenaga kerja, lembaga pendidikan, referensi karyawan atau rekan, serikat buruh, pencangkokan dari perusahaan lain, pasar tenaga kerja, dan sumber-sumber lainnya.

Adapun prosedur perekrutan perusahaan dari suatu sistem rekrutmen oleh Hasibuan (2012) dijelaskan sebagai berikut.

1. Wawancara, yakni suatu wawancara yang secara langsung diselenggarakan oleh para manajer puncak/penyelia dengan seorang pelamar untuk menilai kemampuan potensi pelamar, posisi jabatan, serta penempatan kerja dan tugas yang akan dilakukan oleh pelamar mengingat manajer puncak/penyelia tersebutlah yang akan menjadi atasan langsung dari pelamar jika ia diterima bekerja.

2. Tes potensi akademik, yakni suatu tes yang ditujukan untuk mengetahui bakat dan kemampuan seseorang di bidang keilmuan atau akademis yang sering dikaitkan dengan kecerdasannya.

3. Tes psikogram/psikologi, yakni suatu tes yang menguji kemampuan mental pelamar dalam rangka mengukur kecerdasan, kepribadian, potensial, jenis pekerjaan yang cocok, serta untuk mengukur kesesuaian prestasi kerja yang diberikan dengan apa yang diinginkan oleh penyeleksi.

4. Tes medical check-up, yakni suatu tes yang mengevaluasi medis dengan mengharuskan pelamar untuk menjalani tes kesehatan secara menyeluruh di suatu tempat pemeriksaan oleh dokter yang telah ditentukan perusahaan untuk memastikan bahwa pelamar berada dalam kondisi fisik yang sehat

\section{Penempatan Kerja}

Penempatan merupakan suatu tindak lanjut dari kegiatan seleksi, yakni menempatkan calon karyawan yang diterima pada jabatan yang dibutuhkannya, serta 
sekaligus mendelegasikan wewenang kepada calon karyawan tersebut (Hasibuan, 2012). Menurut Sastrohadiwiryo (2012:162), penempatan kerja adalah suatu proses pemberian tugas dan pekerjaan kepada karyawan yang telah lulus seleksi untuk dikerjakan sesuai dengan ruang lingkup yang ditetapkan, serta untuk mempertanggung jawabkan segala risiko dan probabilitas yang terjadi atas tugas dan pekerjaan, wewenang, serta tanggung jawab yang diberikan kepadanya tersebut. Siswanto (2009:10) menyatakan bahwa penempatan karyawan dilakukan untuk menempatkan karyawan sebagai unsur pelaksana pekerjaan pada posisi yang sesuai dengan kemampuan, kecakapan, dan keahliannya.

Menurut Wahyudi (2008:129), faktor-faktor yang perlu dipertimbangkan dalam penempatan karyawan di antaranya ialah sebagai berikut.

1. Pendidikan, yaitu meliputi pendidikan yang disyaratkan dan pendidikan alternatif.

2. Pengetahuan kerja, yaitu pengetahuan yang dimiliki oleh seorang karyawan dengan wajar sebelum ia ditempatkan dan juga yang baru diperolehnya saat karyawan tersebut ditugaskan dalam pekerjaan yang bersangkutan.

3. Keahlian/keterampilan kerja, yaitu keahlian dalam melaksanakan suatu pekerjaan yang harus diperoleh dalam praktik dan dikelompokkan ke dalam tiga kategori, yakni: (a) keterampilan mental, seperti keterampilan dalam menganalisis data dan membuat keputusan; (b) keterampilan fisik, seperti keterampilan dalam memperbaiki listrik dan mekanik; serta (c) keterampilan sosial, seperti keterampilan dalam mempengaruhi orang lain dan menawarkan produk.

4. Pengalaman kerja, yaitu pengalaman seorang karyawan dalam menjalankan suatu melakukan pekerjaan tertentu.

\section{Kompensasi}

Kompensasi adalah seluruh pendapatan berbentuk uang serta barang langsung ataupun tidak langsung yang diterima oleh karyawan sebagai imbalan atas jasa yang diberikannya kepada perusahaan (Hasibuan, 2012). Rivai (2011) mendefinisikan kompensasi sebagai sesuatu yang diterima oleh karyawan sebagai pengganti atas kontribusi jasa mereka kepada perusahaan. Adapun menurut Sunyoto (2011), kompensasi merupakan suatu jaringan berbagai subproses yang ditujukan untuk memberi balas jasa kepada karyawan atas pelaksanaan suatu pekerjaan dan untuk memotivasi karyawan tersebut agar mampu mencapai tingkat prestasi yang dikehendaki. 
Simamora (2014:442) mengelompokkan kompensasi ke dalam dua jenis, yaitu sebagai berikut.

1. Kompensasi Finansial

Kompensasi ini dapat dibagi lagi ke dalam dua macam, yaitu kompensasi langsung dan tidak langsung. Kompensasi finansisal langsung itu sendiri meliputi bayaran dalam bentuk gaji, upah, dan insentif. Adapun yang dimaksudkan dengan kompensasi finansial tidak langsung (tunjangan) adalah seluruh imbalan finansial yang tidak termasuk ke dalam kompensasi langsung, yakni meliputi program perlindungan (asuransi kesehatan, jiwa dan tanaga kerja serta pensiun), bayaran di luar jam kerja (liburan, hari besar, cuti tahunan dan cuti hamil) dan fasilitas (kendaraan, ruang kantor dan tempat parkir).

2. Kompensasi Nonfinansial

Kompensasi ini adalah kompensasi yang berupa kepuasan seseorang yang diperoleh dari pekerjaannya atau dari lingkungan psikologis dan fisik dimana orang tersebut bekerja. Kompensasi yang terkait dengan pekerjaan di antaranya mencakup tugas yang menarik, tantangan, tanggung jawab, pengakuan, dan rasa pencapaian. Adapun kompensasi yang terkait dengan lingkungan pekerjaan di antaranya mencakup kebijakan yang sehat, supervisi yang kompeten, kerabat kerja yang menyenangkan, dan lingkungan kerja yang nyaman (Simamora, 2014:442).

Menurut Handoko (2012:56), indikator yang dapat dipergunakan dalam mengukur kompensasi karyawan diantaranya adalah sebagai berikut:

1. Gaji pokok, yaitu uang yang dibayarkan kepada seseorang karyawan sebagai balas jasa atas pekerjaan yang dilakukannya.

2. Insentif, yaitu tambahan kompensasi di luar gaji /upah yang diberikan perusahaan.

3. Tunjangan, yaitu meliputi asuransi kesehatan dan jiwa, program pensiun, liburan yang ditanggung perusahaan, dan tunjangan lainnya terkait hubungan kepegawaian.

\section{Kinerja Karyawan}

Kinerja adalah prestasi kerja yang dicapai oleh seseorang. Kinerja juga dapat didefinisikan sebagai kualitas dan kuantitas dari hasil pekerjaan yang dijalankan oleh karyawan sesuai dengan standar kerja yang telah ditetapkan (Mangkunegara, 2011). 
Menurut Wirawan (2009:5), kinerja merupakan suatu keluaran yang dihasilkan berbagai fungsi atau indikator dari suatu pekerjaan atau profesi dalam kurun waktu tertentu. Adapun Bangun (2012) mengartikan kinerja sebagai hasil yang dicapai dari suatu pekerjaan berdasarkan syarat-syarat kerja tertentu.

Menurut Hasibuan (2012:105), faktor-faktor yang mampu memperngaruhi kinerja karyawan antara lain sebagai berikut.

1. Mutu (kualitas), yaitu ukuran hasil pekerjaan yang dihasilkan oleh seseorang yang mencerminkan kemampuan orang tersebut dalam memenuhi standar yang telah ditetapkan perusahaan.

2. Loyalitas (kesetiaan), yaitu kesediaan karyawan dalam menjaga dan membela perusahaan, baik di dalam maupun di luar, dari ancaman orang yang tidak bertanggung jawab.

3. Kreativitas, yaitu kemampuan karyawan dalam mengembangkan keahliannya untuk menjalankan pekerjaannya selain dengan cara yang sudah ditetapkan perusahaan, sehingga karyawan dapat lebih berdaya guna dan berhasil dalam bekerja.

4. Kejujuran, yaitu kedisiplinan karyawan dalam mematuhi berbagai peraturan yang ada dan dalam menjalankan pekerjaannya sesuai dengan instruksi yang telah diberikan.

5. Tanggung jawab, yaitu kesediaan karyawan dalam mempertanggungjawabkan kebijaksanaannya, pekerjaannya, hasil kerjanya, sarana dan prasarana yang dipergunakan olehnya, serta perilaku kerjanya.

\section{Keterkaitan Antarvariabel}

\section{Keterkaitan antara Rekrutmen dan Kinerja}

Salah satu kunci utama dalam pengembangan sumber daya manusia yang berkualitas tinggi adalah rekrutmen. Hal tersebut didukung oleh hasil penelitian yang dilakukan oleh Aziz, dkk. (2017) yang menunjukkan bahwa rekrutmen berpengaruh positif dan signifikan terhadap kinerja karyawan. Pengaruh positif yang signifikan tersebut timbul karena proses rekrutmen yang lengkap dan tepat akan membantu perusahaan untuk dapat merekrut karyawan yang sesuai dengan spesifikasi pekerjaan (job spesification) yang telah ditentukan berdasarkan deskripsi jabatan (job description) yang dibuat melalui serangkaian tahapan dalam analisis jabatan (job analysis). Akibatnya, karyawan yang bersangkutan pun akan mampu untuk menjalankan semua tugas dan pekerjaan yang diberikan kepadanya 
sesuai dengan ekspektasi dan standar yang ditetapkan perusahaan, sehingga kinerja yang tinggi pun akan secara otomatis mampu untuk dicapainya.

$\mathrm{H}_{1}$ : Rekrutmen berpengaruh positif dan signifikan terhadap kinerja karyawan PT Indoturbine Jakarta Pusat.

\section{Keterkaitan antara Penempatan Kerja dan Kinerja}

Agar karyawannya dapat didayagunakan secara optimal, perusahaan juga dinilai perlu untuk memiliki sistem penempatan kerja yang tepat untuk setiap divisi yang ada dalam perusahaan itu sendiri. Dalam hal ini, karyawan yang memiliki kemampuan dan keterampilan untuk menjalankan pekerjaan tertentu diyakini akan lebih tepat jika ditempatkan pada bidang yang sesuai dengan kemampuan dan keahliannya (the right man on the right place) karena karyawan yang tepat tentu akan mampu untuk menjalankan tugas dan pekerjaannya dengan baik, serta mampu untuk menghindari berbagai kesalahan yang mungkin dilakukan dalam pelaksanaan tugas dan pekerjaannya tersebut, sehingga dapat mencapai kinerja yang maksimal. Hal ini sejalan dengan hasil penelitian yang dilakukan oleh Aldilaningsari, dkk. (2014) yang menunjukkan bahwa penempatan kerja yang memperhatikan kesesuaian pengetahuan, kemampuan, dan keterampilan terbukti berpengaruh positif dan signifikan terhadap kinerja karyawan.

$\mathrm{H}_{2}$ : Penempatan kerja berpengaruh positif dan signifikan terhadap kinerja karyawan PT Indoturbine Jakarta Pusat.

\section{Keterkaitan antara Kompensasi dan Kinerja}

Faktor lain yang dinilai dapat mempengaruhi kinerja karyawan adalah kompensasi. Hal ini telah dibuktikan oleh Maharani dan Efendi (2017) dalam hasil penelitiannya yang menunjukkan bahwa kompensasi berpengaruh positif dan signifikan terhadap kinerja karyawan. Keduanya menjelaskan bahwa pemberian kompensasi yang efektif dapat mendorong karyawan untuk menjalankan tugas dan pekerjaannya sebaik mungkin, sehingga pada akhirnya akan mampu untuk meningkatkan kinerja karyawan. Hal tersebut juga didukung oleh hasil penelitian yang dilakukan oleh Aspita dan Sugiono (2018) yang secara spesifik menunjukkan adanya pengaruh positif yang signifikan dari variabel kompensasi finansial terhadap kinerja karyawan. Hal tersebut terjadi karena sistem kompensasi finansial yang baik itu sendiri akan menimbulkan kepuasan kerja bagi 
karyawan, dimana kepuasan kerja tersebut pada akhirnya akan mendorong karyawan untuk senantiasa berkinerja tinggi.

$\mathrm{H}_{3}$ : Kompensasi berpengaruh positif dan signifikan terhadap kinerja karyawan PT Indoturbine Jakarta Pusat.

\section{Kerangka Pemikiran}

Kerangka pemikiran dari penelitian ini dapat dilihat pada gambar sebagai berikut.

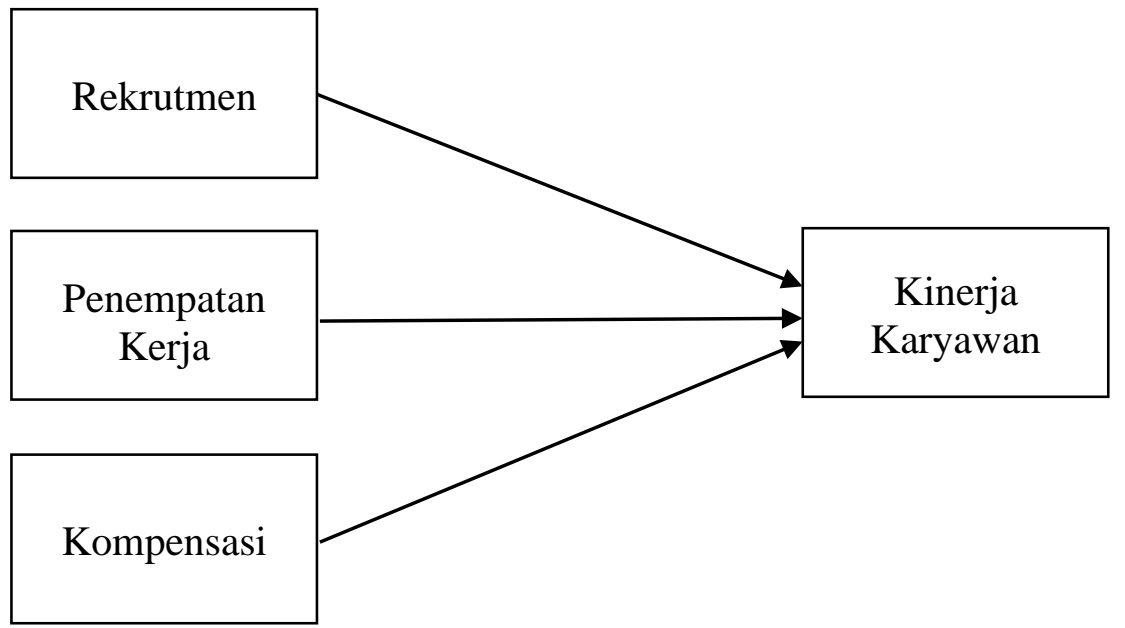

Gambar 1. Kerangka Pemikiran

\section{METODOLOGI PENELITIAN}

\section{Jenis dan Sumber Data}

Penelitian ini menggunakan data cross section dari sumber primer yang diperoleh dari penyebaran kuesioner kepada responden.

\section{Populasi dan Sampel}

Dalam penelitian ini, yang menjadi populasi adalah seluruh karyawan PT Indoturbine Jakarta Pusat yang berjumlah 164 orang. Adapun penentuan jumlah sampel sebanyak 116 responden dilakukan menggunakan rumus Slovin.

\section{Metode Analisis}

Dalam penelitian ini, metode analisis yang digunakan adalah metode analisis regresi linear berganda yang diolah menggunakan SPSS untuk menganalisis pengaruh 
rekrutmen, penempatan kerja, dan kompensasi terhadap kinerja karyawan PT Indoturbine Jakarta Pusat.

\section{HASIL DAN PEMBAHASAN}

Sebelum dianalisis menggunakan regresi linear berganda, instrumen data diuji validitas dan reliabilitasnya terlebih dahulu. Setelah dinilai valid dan reliabel berdasarkan kedua uji instrumen tersebut, data penelitian yang diperoleh dari hasil penyebaran kuesioner kemudian diuji normalitas, heteroskedastisitas, multikolinearitas, dan autokorelasinya. Hasil pengujian asumsi klasik tersebut menunjukkan bahwa data telah terdistribusi normal, sementara model penelitian terbukti telah terbebas dari permasalahan heteroskedastisitas, multikolinearitas, dan autokorelasi.

\section{Hasil Uji Regresi Linear Berganda}

Hasil pengujian regresi linear berganda dapat dilihat pada tabel berikut ini.

Tabel 1. Hasil Uji Regresi Linear Berganda

\begin{tabular}{|l|r|r|r|r|r|}
\hline \multirow{2}{*}{ Model } & \multicolumn{1}{c|}{$\begin{array}{c}\text { Unstandardized } \\
\text { Coefficients }\end{array}$} & \multicolumn{3}{c|}{$\begin{array}{c}\text { Standardized } \\
\text { Coefficients }\end{array}$} \\
\cline { 2 - 6 } & \multicolumn{1}{|c|}{ B } & Std. Error & Beta & \multicolumn{1}{c|}{ t } & \multicolumn{1}{c|}{ Sig. } \\
\hline (Constant) & 5.612 & 1.925 & & 2.916 & .004 \\
Rekrutmen & .294 & .062 & .385 & 4.733 & .000 \\
Penempatan Kerja & .159 & .073 & .179 & 2.173 & .032 \\
Kompensasi & .317 & .100 & .261 & 3.172 & .002 \\
\hline
\end{tabular}

(Sumber: Data diolah, 2019)

Berdasarkan tabel di atas, diperoleh persamaan regresi sebagai berikut.

$$
Y=5,612+0,294 X_{1}+0,159 X_{2}+0,317 X_{3}
$$

Keterangan:

$$
\begin{array}{ll}
\mathrm{Y} & =\text { Kinerja karyawan } \\
\mathrm{X}_{1} & =\text { Rekrutmen } \\
\mathrm{X}_{2} & =\text { Penempatan kerja } \\
\mathrm{X}_{1} & =\text { Kompensasi }
\end{array}
$$




\section{Hasil Uji Kelayakan Model}

Berdasarkan hasil uji F, didapat nilai sig. sebesar 0,000. sehingga model dikatakan layak untuk memprediksi variabel dependen karena nilai sig. tersebut lebih kecil daripada $\alpha(5 \%)$. Dengan kata lain, seluruh variabel bebas dapat secara simultan dan signifikan menjelaskan setiap perubahan pada nilai variabel terikat. Di sisi lain, nilai Adjusted $R$ Square sebesar 0,240 menunjukkan bahwa rekrutmen, penempatan kerja, dan kompensasi memberikan kontribusi sebesar $24 \%$ dalam menjelaskan kinerja karyawan, sedangkan sisanya sebesar $76 \%$ dipengaruhi oleh variabel-variabel lain yang tidak diteliti dalam penelitian ini.

\section{Hasil Pengujian Hipotesis}

Berdasarkan tabel 1, dapat disimpulkan hasil pengujian hipotesis sebagai berikut.

1. Variabel rekrutmen memiliki nilai t positif dan nilai sig. sebesar $0,000<0,05$, sehingga rekrutmen terbukti berpengaruh positif dan signifikan terhadap kinerja karyawan PT Indoturbine Jakarta Pusat.

2. Variabel penempatan kerja memiliki nilai t positif dan nilai sig. sebesar $0,032<0,05$, sehingga penempatan kerja terbukti berpengaruh positif dan signifikan terhadap kinerja karyawan PT Indoturbine Jakarta Pusat.

3. Variabel kompensasi memiliki nilai t positif dan nilai sig. sebesar $0,002<0,05$, sehingga kompensasi terbukti berpengaruh positif dan signifikan terhadap kinerja karyawan PT Indoturbine Jakarta Pusat.

\section{Pembahasan}

\section{Pengaruh Rekrutmen terhadap Kinerja Karyawan}

Hasil penelitian ini menunjukkan bahwa rekrutmen berpengaruh positif dan signifikan terhadap kinerja karyawan PT Indoturbine Jakarta Pusat. Hal tersebut mencerminkan bahwa semakin lengkap dan tepat prosedur rekrutmen yang diselenggarakan oleh perusahaan, maka semakin baik kinerja dari perusahaan tersebut. Sebaliknya semakin tidak lengkap dan tidak tepat prosedur rekrutmen yang diselenggarakan oleh perusahaan, maka semakin buruk kinerja karyawan dari perusahaan tersebut. 
Hasil penelitian ini sejalan dengan hasil penelitian yang dilakukan oleh Aziz, dkk. (2017) dan Kartodikromo, dkk. (2017) yang menunjukkan bahwa rekrutmen secara positif dan signifikan berpengaruh terhadap kinerja karyawan. Hal tersebut terjadi karena proses rekrutmen yang lengkap dan tepat itu sendiri akan membantu perusahaan untuk dapat merekrut karyawan yang sesuai dengan spesifikasi pekerjaan (job spesification) yang telah ditentukan berdasarkan deskripsi jabatan (job description) yang dibuat melalui serangkaian tahapan dalam analisis jabatan (job analysis). Akibatnya, karyawan yang bersangkutan pun akan mampu untuk menjalankan semua tugas dan pekerjaan yang diberikan kepadanya sesuai dengan ekspektasi dan standar yang ditetapkan perusahaan, sehingga kinerja yang tinggi pun akan secara otomatis mampu untuk dicapainya.

\section{Pengaruh Penempatan Kerja terhadap Kinerja Karyawan}

Hasil penelitian ini menunjukkan bahwa penempatan kerja berpengaruh positif dan signifikan terhadap kinerja karyawan PT Indoturbine Jakarta Pusat. Hal tersebut mencerminkan bahwa semakin tepat sistem penempatan kerja yang diterapkan dalam perusahaan, maka semakin baik kinerja dari perusahaan tersebut. Sebaliknya semakin tidak tepat sistem penempatan kerja yang diterapkan dalam perusahaan, maka semakin buruk kinerja karyawan dari perusahaan tersebut.

Hasil penelitian ini sejalan dengan hasil penelitian yang dilakukan oleh Aldilaningsari, dkk. (2014) yang menunjukkan bahwa penempatan kerja yang memperhatikan kesesuaian pengetahuan, kemampuan, dan keterampilan terbukti berpengaruh positif dan signifikan terhadap kinerja karyawan. Muaja, dkk. (2017) juga berhasil membuktikan adanya pengaruh positif dan signifikan dari penempatan kerja terhadap kinerja karyawan. Hal tersebut terjadi karena karyawan yang memiliki kemampuan dan keterampilan untuk menjalankan pekerjaan tertentu diyakini akan lebih tepat jika ditempatkan pada bidang yang sesuai dengan kemampuan dan keahliannya (the right man on the right place) karena karyawan yang tepat tentu akan mampu untuk menjalankan tugas dan pekerjaannya dengan baik, serta mampu untuk menghindari berbagai kesalahan yang mungkin dilakukan dalam pelaksanaan tugas dan pekerjaannya tersebut, sehingga dapat mencapai kinerja yang maksimal. Selain itu, penempatan kerja yang tepat juga mampu meningkatkan mental dan gairah kerja karyawan, sehingga kinerja karyawan tersebut pun akan mampu mencapai hasil yang optimal. 


\section{Pengaruh Kompensasi terhadap Kinerja Karyawan}

Hasil penelitian ini menunjukkan bahwa kompensasi berpengaruh positif dan signifikan terhadap kinerja karyawan PT Indoturbine Jakarta Pusat. Hal tersebut mencerminkan bahwa semakin tepat sistem kompensasi yang diterapkan dalam perusahaan, maka semakin baik kinerja dari perusahaan tersebut. Sebaliknya semakin tidak tepat sistem kompensasi yang diterapkan dalam perusahaan, maka semakin buruk kinerja karyawan dari perusahaan tersebut.

Hasil penelitian ini sejalan dengan hasil penelitian yang dilakukan oleh Maharani dan Efendi (2017) yang menunjukkan bahwa kompensasi secara positif dan signifikan berpengaruh terhadap kinerja karyawan. Keduanya menjelaskan bahwa pemberian kompensasi yang efektif dapat mendorong karyawan untuk menjalankan tugas dan pekerjaannya sebaik mungkin, sehingga pada akhirnya akan mampu untuk meningkatkan kinerja karyawan. Hal ini juga didukung oleh hasil penelitian yang dilakukan oleh Aspita dan Sugiono (2018) yang secara spesifik menunjukkan adanya pengaruh positif yang signifikan dari variabel kompensasi finansial terhadap kinerja karyawan. Hal tersebut terjadi karena sistem kompensasi finansial yang baik itu sendiri akan menimbulkan kepuasan kerja bagi karyawan, dimana kepuasan kerja tersebut pada akhirnya akan mendorong karyawan untuk senantiasa berkinerja tinggi. Sejalan dengan hal tersebut, Pratama, dkk. (2015) juga berhasil membuktikan bahwa kompensasi, baik yang berupa kompensasi finansial maupun nonfinansial, dapat mempengaruhi kinerja karyawan secara positif dan signifikan.

Pemberian kompensasi yang dilakukan secara adil berdasarkan pencapaian yang diraih oleh karyawan pada dasarnya akan membuat karyawan yang bersangkutan merasa dihargai kontribusinya. Sebaliknya, Manullang (2001) dalam Sugiono dan Rachmawati (2018) menyebutkan bahwa perusahaan yang tidak memberikan motivasi ekstrinsik yang sesuai kepada karyawannya, termasuk motivasi dalam bentuk kompensasi seperti gaji/upah, tunjangan dan jaminan keselamatan kerja, biasanya akan dihadapkan pada masalah berupa kenaikan tingkat kemangkiran karyawan yang pada akhirnya berdampak pada ketidak optimalan kinerja karyawan. 


\section{KESIMPULAN DAN SARAN}

\section{Kesimpulan}

Berdasarkan hasil penelitian ini, maka dapat ditarik kesimpulan bahwa rekrutmen, penempatan kerja, dan kompensasi secara parsial berpengaruh positif dan signifikan terhadap kinerja karyawan PT Indoturbine Jakarta Pusat.

\section{Saran}

Dari kesimpulan di atas, penulis mengemukakan saran sebagai berikut.

1. Perusahaan hendaknya lebih memperhatikan proses rekrutmen yang diselenggarakannya agar karyawan yang direkrut dapat mencapai kinerja yang tinggi.

2. Perusahaan hendaknya lebih memperhatikan pertimbangan-pertimbangan dalam penempatan kerja agar setiap karyawannya dapat ditempatkan pada tugas dan pekerjaan yang sesuai dengan kapasitasnya, sehingga kinerja karyawan pun dapat dioptimalisasi.

3. Perusahaan hendaknya senantiasa berupaya menerapkan sistem kompensasi yang tepat kepada karyawannya agar karyawan dapat terdorong untuk berkinerja tinggi.

\section{DAFTAR PUSTAKA}

Aldilaningsari, Y., M.A. Musadieq, dan M.S. Hakam. 2014. Pengaruh Penempatan Kerja terhadap Kinerja: Studi pada Karyawan PT Bank Jatim Cabang Malang. Jurnal Administrasi Bisnis. 9(1): 1-7.

Aspita, M. dan E. Sugiono. 2018. Pengaruh Jenjang Karir, Kompensasi Finansial dan Status Karyawan terhadap Kinerja Karyawan Bank Rakyat Indonesia Cabang Daan Mogot. Jurnal Ilmu Manajemen Oikonomia. 14(1): 1-14.

Atikawati, E. dan R. Udjang. 2016. Strategi Rekrutmen dan Seleksi terhadap Kinerja Karyawan. JPSB. 4(1): 9-23.

Aziz, T.A., M.S. Maarif, dan A Sukmawati. 2017. Pengaruh Rekrutmen dan Seleksi terhadap Kinerja. Jurnal Aplikasi Bisnis dan Manajemen. 3(2): 245-253.

Bangun, W. 2012. Manajemen Sumber Daya Manusia. Erlangga. Jakarta.

Handoko, T.H. 2012. Manajemen Personalia dan Sumber Daya Manusia. BPFE. Yogyakarta.

Hasibuan, M.S.P. 2012. Manajemen Sumber Daya Manusia. Bumi Aksara. Jakarta. 
Kartodikromo, E.A., B. Tewal, dan I. Trang. 2017. Proses Rekrutmen, Seleksi, Pelatiha Kerja dan Pengaruhnya pada Kinerja Karyawan CV Celebes Indonesia Sakti MER 99 Mega Mas Manado. Jurnal EMBA. 5(2): 354-372.

Maharani, I. dan S. Efendi. 2017. Pengaruh Budaya Organisasi, Komitmen Organisasi, Kompensasi dan Etos Kerja terhadap Kinerja Pegawai Kementerian Ketenagakerjaan Republik Indonesia. Jurnal Ilmu Manajemen Oikonomia. 13(2): 49-61.

Mangkunegara, A.A.A.P.2011. Manajemen Sumber Daya Manusia Perusahaan. PT Remaja Rosda Karya. Bandung.

Manullang, M. 2001. Manajemen Sumber Daya Manusia. BPFE. Yogyakarta.

Muaja, K.O., Adolfina, dan. L.O.H. Dotulong. 2017. Pengaruh Penempatan Kerja dan Pengalaman Kerja terhadap Kinerja Karyawan pada PT Bank Sulutgo Kantor Cabang Utama Manado. Jurnal EMBA. 5(2): 2211-2220.

Pratama, S.A., M.S. Hakam, dan G.E. Nurtjahjono. 2015. Pengaruh Kompensasi terhadap Kinerja Karyawan: Studi pada Karyawan PT Asuransi Jiwasraya Persero Regional Office Malang. Jurnal Administrasi Bisnis. 25(1): 1-8.

Rivai, V. 2011. Manajemen Sumber Daya Manusia untuk Perusahaan: dari Teori dan Praktik. Raja Grafindo Persada. Jakarta.

Sastrohadiwiryo, B.S. 2012. Manajemen Tenaga Kerja Indonesia: Pendekatan Administrastif dan Operasional. Bumi Aksara. Jakarta.

Simamora, H. 2014. Manajemen Sumber Daya Manusia. Edisi 3. STIE YKPN. Yogyakarta.

Siswanto. 2009. Pengantar Manajemen. Bumi Aksara. Jakarta.

Sugiono, E. dan W. Rachmawati. 2019. Pengaruh Gaya Kepemimpinan Transformasional, Budaya Organisasi dan Motivasi Ekstrinsik terhadap Kinerja Karyawan PT Semen Padang, Jakarta Selatan. Jurnal Ilmu Manajemen Oikonomia. 15(1): 57-69.

Sunyoto, D. 2012. Manajemen Sumber Daya Manusia. Center for Academic Publishing Service. Jakarta.

Sutisna, D. 2011. Manajemen Sumber Daya Manusia. Edisi Kedua. BP USB. Bandung.

Wahyudi. 2008. Manajemen Konflik dalam Organisasi. Alfabeta. Bandung.

Wirawan. 2009. Evaluasi Kinerja Sumber Daya Manusia: Teori Aplikasi dan Penelitian. Salemba Empat. Jakarta. 